Izvorni znanstveni rad DOI: $10.17234 /$ Croatica.65.1

UDK: 811.163.42’282(091)

821.163.42.09-1'"15',

(497.584 Dubrovnik)

811.163.42:801.7

Primljen: 16. V. 2020.

Prihvaćen: 21. X. 2020.

\title{
POGLED NA JEZIK PJESNIŠTVA LIBRA OD MNOZIJEH RAZLOGA U KONTEKSTU HRVATSKIH MEĐUDIJALEKTNIH ADAPTACIJA 16. STOLJEĆA
}

\author{
Vera Blažević Krezić \\ Sveučilište Josipa Jurja Strossmayera u Osijeku, Filozofski fakultet \\ vblazevic1@ffos.hr \\ Ivana Eterović \\ Sveučilište u Zagrebu, Filozofski fakultet \\ isankovi@ffzg.hr
}

U hrvatskome ćiriličkom korpusu važno mjesto zauzima dubrovačka sastavnica u kojoj je rukopisna ćirilička tradicija njegovana stoljećima i koja obuhvaća tekstove različitih funkcionalnih registara, posebice bogata u 16. stoljeću. Među opsežnijim tekstovima dubrovačke ćiriličke pismenosti nalazi se i Libro od mnozijeh razloga, zbornik pretežno nabožnoga sadržaja iz 1520. godine. Objavljujući ga u cijelosti prije stotinjak godina, Milan Rešetar ustvrdio je da su njegovi članci nastali pod utjecajem različitih predložaka „okrenutih” na dubrovački govor: glagoljičkih na narodnome i ćiriličkih na crkvenoslavenskome jeziku te talijanskih, a pronašao je čak i kajkavski utjecaj. Takvo „okretanje na dubrovački” nije isključiva značajka Libra od mnozijeh razloga, već je međudijalektna adaptacija potvrđena i u drugim hrvatskim tekstovima 16. stoljeća. U ovome radu prikazuju se razine čakavsko-štokavske prilagodbe u jeziku Libra na primjeru dviju njegovih pjesama, a potom uspoređuju s drugim primjerima čakavsko-štokavskih i 
čakavsko-kajkavskih prilagodbi iz 16. stoljeća, čime se teži dati prilog boljem razumijevanju odnosa među hrvatskim narječjima i dijalektima u ranome novovjekovlju.

Ključne riječi: hrvatski jezik, 16. stoljeće, ćirilica, Dubrovnik, Libro od mnozijeh razloga, pjesništvo, međudijalektna adaptacija, horizontalni prijevod

\section{UVOD}

Libro od mnozijeh razloga (1520) šesnaestostoljetni je izdanak onomad visokorazvijene dubrovačke ćiriličke pismenosti koja među srednjojužnoslavenskim pismenostima zauzimlje posebno mjesto. Ta neotuđiva tekovina zapadnoćiriličke tradicije ${ }^{1}$, što je svoj grafomorfološki/ortografski razvojni put ${ }^{2}$ stala razvijati u zahumsko-dukljanskim pisarskim središtima 10. i 11. stoljeća, ${ }^{3}$ jedinstvena je pojava hrvatske književno-jezične prošlosti, uklopiva u krilaticu akademika Eduarda Hercigonje o našoj tropismenoj i trojezičnoj srednjovjekovnoj kulturi $\left({ }^{1} 1994,{ }^{2} 2006\right)$. I dok je glagoljična sastavnica netom spomenuta Hercigonjina izraza u srednjemu vijeku prevladavala - što kvalitetom, što kvantitetom, oblici sestrinske ${ }^{4}$ ćiriličke pisme-

1 O terminu zapadna ćirilica, izazovima vezivanja tipova i spomenika zapadnoćiriličke pismenosti za (samo) jednu nacionalnu kulturu (osobito do 15/16. stoljeća) vidjeti više u: Raukar 1973, Žagar 2009, Zelić Bućan 2000 i dr.

2 Posebnost zapadne ćirilice ogleda se u čitavu vizualnome/grafetičkome/tekstnome postavu, ali i u slovnome inventaru (primjerice redukcijama slovnih viškova i dijakritika, ili pak učestaloj uporabi jata za glasovni slijed /ja/, odnosno uvođenju glagoljskoga đerva i njegovih novih funkcija: bilježenja glasa /đ/, poslije i glasa /ć/ u štokavskim, bosanskim i dubrovačkim tekstovima); uopćeno govoreći - u izraženoj propusnosti kontaktne glagoljičke i latiničke pismenosti (usp. Žagar 2009: 200-202).

3 Koji su sukus tzv. zetsko-humske redakcije ili škole staroslavenskoga jezika (prema akademiku Vojislavu Nikčeviću riječ je o zetskoj, odnosno crnogorskoj redakciji staroslavenskoga jezika, usp. Lukić 2009: 23, vidi i Damjanović 2012: 183-186, 195-196). U pogledu srednjovjekovnih i ranonovovjekovnih redakcija/recenzija do danas nije postignuta terminološka i korpusna ujednačenost pa je tako otvorenim ostalo pitanje statusa južnoslavenskih (pod)redakcija - bosanske i crnogorske (zetsko/-humske/) (Mihaljević 2009: 286). Primjerice na termin bosanska redakcija ne pristaju čak ni neki bosanski slavisti, i to stoga što - uvažavajući polazišne manjkavosti termina redakcija i recenzija (Damjanović 2012: 143), ali i kriterij različitosti govorne podloge - prednost daju nazivu škola (usp. Žagar 2020a: 315). Terminološka pa čak ni korpusna usuglašenost nije se ostvarila, kako vidjesmo, ni u zetsko-humskoj/ zetskoj/crnogorskoj redakciji staroslavenskoga jezika. Postavlja se također pitanje možemo li istom redakcijom nazivati jezik koji na staroslavensku osnovicu naslojava čakavski, odnosno srednjojužnoslavenski (štokavski) jezik (usp. Žagar 2008: 697).

4 Napose ako pojavu i širenje glagoljičke i ćiriličke pismenosti hrvatskoga kulturnoga prostora stanemo razmatrati u okviru nadređena pojma ćirilometodske baštine (usp. Žagar 2009: 193, Lukić 2011: 77, Damjanović 2016: 73). 
nosti, što su donedavna uznemiravali jednoobrazne nacionalno-političke i filološke modele (gdjekad je tomu i dan-danas tako), slabije su bili istraženi i eksponirani. Ta je pismovna ograda, sukladno zastarjelim devetnaestostoljetnim filološkim pogledima (usp. Žagar 2008: 695), tijesno bila povezana s jezičnom: drukčije se, naime, promatrala glagoljička pismenost, što uz crkvenoslavenski jezik zastupa čakavski, odnosno miješani vernakular, od ostalih srednjojužnoslavenskih pismenosti (ćiriličke, latiničke), koje su jasnije ukazivale na dijakronijske i dijatopijske varijacije štokavskoga vernakulara.

Podsjetimo, ćiriličkim se pismom na hrvatskim kulturnim prostorima pisalo od 11. do 19/20. stoljeća, pretežno na tzv. istočnome krilu hrvatskoga glagoljaštva (južna Dalmacija, dubrovačko područje, Hum, Bosna, ali i sjeverniji krajevi, pa čak i Banska Hrvatska, Slavonija..., usp. Žagar 2009: 152, Žagar 2016: 12). Tim su pismom Hrvati zadovoljavali svakovrsne komunikacijske potrebe, a upravo je polifunkcionalnost hrvatskoga ćiriličkoga izraza ukazivala na unutarnju jednako koliko i vanjsku (diplomatsku) potrebu njegova poznavanja (usp. Damjanović 2016: 73). Zadarski je paleoslavist i paleokroatist Ivan Berčić među prvima istaknuo razvojna središta hrvatske - tiskopisne i rukopisne - ćiriličke tradicije: bosansko i humsko, srednjo- i južnodalmatinsko te dubrovačko, organiziravši 1863, kao dodatak svojoj knjižici Bukvar staroslovenskoga jezika glagolskimi pismeni za čitanje crkvenih knjig objavljenoj 1860, poglavlje pod nazivom Glagolska i bosanska rukopisna azbukva.

Maločas spomenuta ćirilička polifunkcionalnost, u kontinuitetu očitovana od samih početaka uporabe ovoga pisma na hrvatskim prostorima pa sve do devetnaestostoljetnih (čak i dvadesetostoljetnih) prežitaka, spomeničkom je baštinom zastupljena i na dubrovačkome području. Podsjetimo, ćirilica dubrovačkoga kraja dominantnom je opcijom tamošnjega hrvatskoga književnojezičnoga izraza sve do 16. stoljeća, kada latinica i zapadna ćirilica, nakon uzmicanja glagoljice, i dalje odmjeravaju snage, ali se na širemu planu nazire latinička pobjeda. Usto u pisanu se izrazu susreću stara dubrovačka i nova hercegovačka štokavština (Damjanović 2014: 49). Vjerujemo stoga da se važnost Libra za cjelinu hrvatske pisane kulture među ostalima sagledava upravo u pokušajima takva kontekstualiziranja: povrh svega uporabe ćiriličkoga pisma u hrvatskoj srednjovjekovnoj i (rano)novovjekovnoj kulturi. Imanentnost hrvatske ćiriličke pismenosti očitovana je njezinom višefunkcionalnošću pa se valjani pregledi dubrovačke ćiriličke tradicije baziraju na raščlanjivanju tekstova liturgijskoga, književnoga i administrativno-pravno- 
ga/diplomatičkoga karaktera (usp. Žagar i Paskojević 2014; Žagar 2021). ${ }^{5}$ S tekstovnim se registrima usklađivala i pismovna stilizacija, što znači da je baš na dubrovačkome prostoru izvrsno zasvjedočena razvojna linija ćiriličke minuskule - pisma na prijelazu ustava u kurziv/brzopis. Mateo Žagar k tomu, potaknut dugogodišnjim proučavanjem historiografske i filološke literature na tu temu, kao i radom na samim izvorima, razlikuje knjišku (vjerojatno razvijenu prema diplomatskoj/diplomatičkoj) i kancelarijsku (diplomatsku/ diplomatičku) minuskulu, a potom i novovjeki brzopis/kurziv (Žagar 2014: 147-172, Žagar 2021, usp. i Paskojević 2018). Sustavno opisuje i narav hrvatskoga ćiriličkoga tiska čiji je prvotisak, molitvenik otisnut 1512. godine (21571.), također dubrovački proizvod. ${ }^{6}$

5 Liturgijski korpus čine Dubrovački/Dominikanski lekcionar s početka 16. stoljeća (štokavsko-ćirilska prilagodba čakavskoga Bernardinova lekcionara iz 1495, no ne samo njega, usp. Rešetar 1933b: 118, Barbarić 2017: 96) i Lajpciški lekcionar iz treće četvrtine 16. stoljeća (štokavsko-ćirilska prilagodba drugoga izdanja Bernardinova lekcionara iz 1543, usp. Rešetar 1933b: 12, Barbarić 2017: 105). Spomenimo Rešetarovu pretpostavku prema kojoj je jedan od pisara Libra, tzv. pisar A, zapravo ispisao i Dominikanski lekcionar (usp. Rešetar 1933b: 120), a što je - sukladno novijim grafolingvističkim istraživačkim standardima - potrebno sustavnije ispitati (Kapetanović 2014, Barbarić 2017, Žagar 2021). Uz ćiriličke stihove latinskoga Carinskoga statuta (između 1421. i 1431), lijepu dubrovačku riječ zapisanu ćirilicom zasigurno zastupa rukopisni zbornik Libro od mnozijeh razloga iz 1520. godine, koji su, pod vodstvom profesora Matea Žagara, studenti diplomskoga studija kroatistike na Filozofskome fakultetu u Zagrebu prepisali latinicom 2020. godine. Dubrovačkom minuskulnom ćirilicom prepisan je i molitvenik Raj duše ozaljskoga autora Nikole Dešića (otisnut u Padovi 1560. godine, latinski izvornik: Hortulus animae), i to 1567. pod naslovom Ortus anime itd. Diplomatsku minuskulu, poslije i brzopis zastupaju spomenici što nastaju u kontinuitetu od 11. stoljeća (kada ona još uvijek nije u cijelosti formirana) - počevši s dubrovačkim prijepisima Povelje/Listine Kulina bana (1189) - sve do tekstova dubrovačke slavenske kancelarije u kojoj su se istaknuli pisci kao što su Đivo Parmezan, Niko Bijelić, Vidoš Bogdanić (iz 14. st.), Rusko Hristoforović, Marinko Cvjetković, Nikša Zvijezdić (iz 15. st.) (usp. Žagar i Paskojević 2014). U potonjega autora osobito se dobro prepoznaje kurzivni ćirilički predznak (usp. Paskojević 2018: 375). Tako definiranu ćiriličku minuskulu treba razlikovati od kurziva razvijenoga u Bosni 16. stoljeća, koji se, u nekih autora, naziva bosančicom.

6 Ofičje Blažene Djeve Marije i Petnaest molitava Svete Bridžide, molitvenik otisnut 1512. godine u Veneciji, hrvatski je ćirilički prvotisak čiji je faksimilni pretisak s komentarom akademkinje Anice Nazor pripremljen 2013. godine, dok su latinički prijepis 2016. godine pripremili studenti izbornoga kolegija Hrvatska ćirilička pismenost pri Filozofskome fakultetu u Zagrebu, a pod vodstvom profesora Matea Žagara. Pismo i jezik toga spomenika vjeran su odraz knjiške ćirilske minuskule s jedne, odnosno dubrovačke šesnaestostoljetne štokavštine s druge strane. Ćirilskim tiskovinama dubrovačkoga kraja zasigurno valja pridružiti Nauk karstianski Jacoba/Jakova Ledesme, otisnut u Veneciji 1583. Pismo te knjižice između je uzusa ustavne, minuskulne i brzopisne ćirilice - tzv. ustavizirana minuskula; s velikim brojem rješenja bliskih uporabi u knjigama čvrsto naslonjenima na staroslavensku, pa i istočnu 


\section{LIBRO OD MNOZIJEH RAZLOGA}

Zbornik Libro od mnozijeh razloga nepotpuni je rukopis koji sačinjavaju književni tekstovi srednjovjekovnoga karaktera razvrstani u pet temeljnih dijelova ispisanih od četvorih dubrovačkih pisarskih ruku. Njime se temeljito bavio hrvatski jezikoslovac Milan Rešetar u dvjema svojim knjigama. Godine 1926. objavljuje ćirilički prijepis Libra od mnozijeh razloga u Zborniku za istoriju, jezik i književnost srpskog naroda Srpske kraljevske akademije, i to u nizu Spomenici na srpskom jeziku. Smatra da se osnovna vrijednost Libra krije u njegovu jeziku: to je, prema Rešetaru, „svakako najstariji književni štokavski spomenik [...] pisan ćirilicom" (Rešetar 1926: XVII), odnosno „najstariji naš književni spomenik pisan ćirilicom a narodnim - ne crkvenim - jezikom" (Rešetar 1933b: IX), dok o njegovoj književnoj vrijednosti nema osobito visoko mišljenje. Već je tada naumio objaviti opsežnu studiju o sadržaju i jeziku Libra, koja će ugledati svjetlo dana 1933. godine u Posebnim izdanjima Srpske kraljevske akademije.

Pismo motrenoga kodeksa Rešetar opisuje kao bosansku ćirilicu

koja uprav nije nikakvo specijalno bosansko pismo, nego je starija ćirilska minuskula koja je u starije vrijeme bila u običaju u svim našim krajevima u kojima se uopće pisalo ćirilicom, i kod pravoslavnih i kod katolika i kod muslimana, dok je nije kod prvih zamijenilo izvan crkve, u kojoj je ostalo majuskulno 'ustavno' pismo - rusko 'građansko' pismo, a kod katolika u Primorju latinica, tako da je od XVIII. vijeka ostala ograničena na katolike i muslimane u Bosni i Hercegovini, a naročito na ove posljednje otkada su nekako od prve polovice prošloga vijeka i tamošnji katolici sasvim prihvatili latinicu. (1926: XII)

Na drugome pak mjestu precizira: „Zato bih ja i volio zvati naš skoropis minuskulom, jer, kako ćemo odmah vidjeti, skoro nema nikako karakter 'skoroga' ili kurzivnoga pisma. Vrlo je pak obična stvar da se naš skoropis zove ‘bosanskim pismom' ili ‘bosančicom', što nije nikako opravdano, jer on niti je postao u Bosni, niti je bio na Bosnu ograničen." (1933b: 122)

ćiriličku tradiciju (dubrovački štokavsko-(i)jekavski govor s primjesama crkvenoslavenskoga) (usp. Štefanić 1938: 21-27, Žagar 2014: 153). O dubrovačkoj (i)jekavskoj štokavštini više u: Lovrić Jović 2014: 44-47, 246, posebno ističemo Milanom Mogušem usmjerenu napomenu da se pripadnost sustavu ogleda u odrazu jata gramatičkih morfema. 


\subsection{O jeziku Libra od mnozijeh razloga}

U drugoj polovici 19. stoljeća Vatroslav Jagić objavljuje pojedine dijelove Libra od mnozijeh razloga u svojem djelu Prilozi k historiji književnosti naroda hrvatskoga i srbskoga. Pišući o tekstu Cvijet kreposti, ${ }^{7}$ kojim Libro započinje, ocjenjuje da je pisan ,jezikom čistiem narodniem, prostiem od upliva jezika crkvenoga" te iznosi pretpostavku da je njegov prevoditelj, odnosno pisac bio „nekakav bosansko-dalmatinski fratar, onakova reda čovjek, kao što su kasnije Divković, Posilović itd.” (Jagić 1868: 4) Želeći svojoj pastvi omogućiti upoznavanje s onodobnom „religiozno-popularnom literaturom", najlakše im je bilo, nastavlja Jagić, prevesti nešto s talijanskoga ili latinskoga jezika s obzirom na to da su se školovali mahom u Italiji (Jagić 1868: 4-5).

S tom se pretpostavkom neće složiti Milan Rešetar koji u predgovoru ćiriličkom prijepisu Libra od mnozijeh razloga ustvrđuje da su svi njegovi dijelovi „okrenuti na dubrovački govor što sa čakavsko-glagolskih matica na narodnom jeziku a što sa crkvenih, valjada ćirilskih, ili su prevedeni s talijanskog jezika; može se napokon konstatovati da je nešto uzeto preko matice što je prevođena ili prepisivana od kajkavca." (Rešetar 1926: XVI) Pretpostavlja da su izvori, odnosno predlošci različiti, ali da ništa nije „baš dubrovački originalni rad" (Rešetar 1926: XVI). Nakon što je proučio cijeli rukopis, na temelju pojedinih tipično dubrovačkih jezičnih značajki zaključuje da su ga zasigurno pisali Dubrovčani (pisari A, B i C); štoviše,

7 Godine 2020. Antonija Zaradija Kiš i Marinka Šimić taj su europski bestseller za razdoblje od 14. do 18. stoljeća sustavno istražile u starijemu hrvatskomu književnomu korpusu, posebice onomu iz zlatnoga doba hrvatskoga glagoljaštva (Vinodolski zbornik, Petrisov zbornik, Ljubljanski zbornik, Tkonski zbornik, Grškovićev zbornik), ali i u ćiriličkoj (Libro od mnozijeh razloga, Cviet od kriposti fra Pavla Posilovića iz 1647. i 1701) te latiničkoj tradiciji (peraški Cvijet od kriposti Krste Mazarovića iz 1712). Budući da studija istaknutih autorica uz filološko-kulturološki uvod donosi i iscrpnu jezičnu analizu spomenutih hrvatskih prijevoda Cvijeta kreposti (2020: 75-93), ondje se daju - usporedno uzete i obilato oprimjerene - podrobnije motriti jezične odlike toga dijela Libra, pa i one zanimljive vizuri ovoga rada koja se oslanja na pitanje priređivačeve, tj. recipijentske percepcije međudijalektnoga obrata/prilagodbe (prvenstveno čakavštine u štokavštinu). Izdvajamo primjere Librova dosljednoga jekavskoga odraza jata (grafemskim slijedom ie za ije i je, npr. koliena, vriemena, cvietb, čoviekb, besiede), pa zamjenu slogotvornoga $l$ glasom i slovom $u$ (npr. pukb, punb), bilježenje slijeda $c r$ - na mjestima tipične hrvatskoglagoljske skupine $\check{c} r$ - ( $\check{r} r$ lenu : carlenu), a s razine oblika odnos relativne i upitne zamjenice stegnuta oblika ki, ka, ko prema Librovu Cvijetu s oblicima koi, koja, koje, odnosno prevagu prezentskih oblika za 1 . lice jd. na -am, -im i -em umjesto na -ju/-u (prebivamb, molimb, poviemb). 
pretpostavlja da je glavni pisar (A) bio s otoka Mljeta i da je cijeli rukopis možda nastao u mljetskome benediktinskom samostanu (Rešetar 1926: XIV-XV). Ta Rešetarova pretpostavka bit će problematizirana u nedavno objavljenoj studiji Matea Žagara i Dolores Grmača koji suprotno Rešetaru vezuju Libro upravo za - urbanu kulturu (2020: 20, 33-35, 57). ${ }^{8}$

Isti će zaključak Rešetar ponoviti i u svojoj opsežnoj studiji o sadržaju i jeziku Libra od mnozijeh razloga gdje ponovno ističe da su svi članci ili prevedeni ili prerađeni od Dubrovčana (u širem smislu) te naglašava da se njihove jezične značajke međusobno razlikuju: prvi bi bili pisani „na čistom dubrovačkom govoru”, a drugi „okrenuti na dubrovački govor” uz veću ili manju zastupljenost „čakavskoga dalmatinskoga dijalekta” kojim je bio pisan njihov predložak, dok bi elementi crkvenoslavenskoga jezika bili zastupljeni u primjesama ili tragovima (Rešetar 1933b: 116-117). ${ }^{9}$ Taj bi čisti ili živi narodni dubrovački govor bio štokavsko-jekavski dijalekt „kako se govorio (i još govori) u Dubrovniku i njegovoj okolici u drugoj polovici XV. vijeka i u prvoj polovici XVI-oga" (Rešetar 1933b: 116).$^{10} \mathrm{U}$ svojoj studiji Rešetar najprije opisuje jezik Libra, a potom ga uspoređuje sa starijim dubrovačkim proznim tekstovima: dubrovačkim poveljama nastalim od 13. do 15. stoljeća i Ranjininim lekcionarom iz 1508. godine, pričem je njegov cilj steći uvid u razvoj dubrovačkoga dijalekta do početka 16 . stoljeća (Rešetar 1933b: 120).

8 Usp. npr.: „Ako i ne zaključujemo, unatoč zapisu, da je Libro i prepisano u samome Gradu, ne bi trebalo biti sumnje da je bilo (i) za Grad namijenjeno." (Žagar i Grmača 2020: 20)

9 Pišući o dvjema inačicama pjesme Tužba: Probudi se jure, duše, Stjepan Ivšić također govori o prevođenju ikavskog originala, odnosno okretanju čakavskoga glagoljskog teksta na dubrovački jekavski govor (1932: 4, 9).

10 Suvremena hrvatska dijalektologija smatra da je u predmigracijskome razdoblju dubrovački dijalekt, uključujući ne samo govor grada Dubrovnika već i otoke pred njim, Cavtat i Konavle, bio samostalnim zapadnoštokavskim dijalektom, i to štakavskoga tipa s ijekavskim refleksom jata (Lisac 2009: 273; Lisac 2011: 65; Lukežić 2012: 284). Budući da je granica između čakavštine i štokavštine prolazila u blizini Dubrovnika, ostavljajući istočni Pelješac i Mljet u zapadnoj štokavštini, a zapadni Pelješac, Korčulu i Lastovo s ostalim otocima prema zapadu u čakavštini, uslijed takva jezičnoga kontakta pojedini su čakavizmi postali sastavnim dijelom dubrovačkoga govora (Lisac 2011: 65; Lukežić 2012: 269). Iva Lukežić razdvaja pak govore dubrovačkoga područja, istočnoga Pelješca i Mljeta predmigracijskoga razdoblja u dva dijalekta: ijekavsko-ikavski istočnopelješki pridružuje poneretvanskom, a (i)jekavski dubrovačko-mljetski izdvaja posebno (Lukežić 2012: 269). Danas je dubrovački dijalekt poddijalektom istočnohercegovačko-krajiškoga dijalekta koji će nakon velikih migracija u 16. stoljeću postati s vremenom najvećim srednjojužnoslavenskim dijalektom (Lisac 2011: 64-67). 
Naravno, poznato je da se između materinske (organske) dubrovačke štokavštine 16. stoljeća i njezina života u pisanome/književnome jeziku i tako ne može povući znak jednakosti, na što su nas upozoravali proučavatelji kanona stare hrvatske književnosti rekavši kako je dijalektna književnost svojina 20. stoljeća te da nijedan dopreporodni pisac nije pisao svojim govornim jezikom (usp. Franičević 1964, Damjanović 1984, Vončina 1987). Stilizacija je stoga uvijek uočljiva, što valja imati na umu prilikom razmatranja Rešetarove tvrdnje (1933b: 116) kako su sa stranih jezika prevedeni dijelovi Libra napisani na čistom dubrovačkom govoru, dok su međudijalektne preradbe podrazumijevale nejednakom dosljednošću provođeno okretanje na dubrovački govor, prvenstveno prema polazišnoj čakavskoj matici. ${ }^{11}$ Drugim riječima, čakavski elementi Libra vezani su za predloške (ili barem tekstne paralele) čakavsko-glagoljske matice, pa i za južnije dalmatinske izvore. Dubrovački je govor međutim poznavao i organske čakavske elemente (Malić 1980: 148, Lovrić Jović 2014). Crkvenoslavenske primjese i tragovi - o kojima Rešetar također piše (1933b: 92-98) - usko su vezani za čakavsko-glagoljske matice, dok konzistentniju crkvenoslavenštinu Libra povezuje s istočnom (ćirilskom) crkvenoslavenskom književnosti, što se vidi u njegovoj razradi Librova petoga dijela: gdje članke nastale preradom glagoljsko-čakavskih matica, s crkvenoslavenskim primjesama (npr. Čtenje

11 Rešetar drži da samo pjesnici stiliziraju, dok prozna djela i spisi vjerno odražavaju narodni dubrovački govor: „Nema sumnje dakle da nam do kraja XVI. vijeka dubrovačka proza a ne dubrovačka poezija pretstavlja živi narodni dubrovački govor, tako da bi se sa Z-om mogle ispoređivati iz dubrovačke pjesničke literature toga vremena samo Držićeve komedije u prozi i to ponajviše dosta kratki predgovori i posvete. Prozna književnost u tu bi nam svrhu dabome vrlo dobro došla, prije svega poznata pobožna djela B. Gradića i Ark. Gučetića, i još dvije manje stvari, a onda naročito još četiri dubrovačka djela XVI. vijeka što su pisana ćirilicom kao i Z." (Rešetar 1933b: 117-118). Sanja Vulić (2016: 230) međutim utvrđuje da se usporednom analizom (proznih) književnih i neknjiževnih dubrovačkih tekstova 16. stoljeća, uza sve spomenute ograde, otkriva značajna utemeljenost književnojezičnih rješenja u onodobnomu dubrovačkomu govoru. Ivana Lovrić Jović terminu dubrovački govor stoga sup(r)o(t)stavlja izraz dubrovački jezik (2014: 2-3), a oba natkriljuje sintagmom dubrovački idiom koja sadržajem zaista zahvaća organski govor grada Dubrovnika, no potonji je jasno, za minula povijesna vremena kakvo je 16. stoljeće, nemoguće drukčije istražiti doli posredno - ispitivanjem dubrovačkoga književnog jezika. Za osamnaestostoljetne frančezarije Lovrić Jozić utvrđuje da su pisane živim dubrovačkim govorom u prozi, toliko slobodnim da ih se ne može nazvati prijevodima, nego preradbama, tim više što su se naslanjale ne samo na Molièreove francuske izvornike nego i na prijašnju hrvatsku tradiciju prevođenja toga autora i korpusa (2014: 18, 23), i ne samo njega odnosno njih (primjeri knjiških ekavizama celov, telesne). Osim toga morfologija više negoli fonologija frančezarija prokazuje različitost onodobnoga pjesničkog i proznog jezika (2014: 248), poglavito sustav množinskih imeničkih padeža Gundulićeva jezika s jedne te jezika frančezarija i oporuka s druge strane. 
Brnarda, Čtenje sv. Ambroža, Čtenje od Aluberta, Čtenje od bl. Agustina), suprotstavlja 34. poglavlju (Skazanje od 12 petaka), čiji se intenzitet crkvenoslavenštine gotovo ne ponavlja nigdje drugdje u Zborniku ${ }^{12}$, a povezan je $\mathrm{s}$ istočnim/ćirilsko-crkvenoslavenskim izvorima, premda Rešetar spominje i hrvatskoglagoljske paralele (usp. Vugrinec 2010).

Jezik je spomenika u svakome slučaju nejedinstven, a rezultat je inojezičnih prijevoda s jedne i unutarjezične (međudijalektne ${ }^{13}$ ) prilagodbe s druge strane. Članci moralno-filozofskoga, legendarnoga, apokrifnoga i pobožnoga karaktera podvrgavani su različitim stupnjevima prilagodbe onodobnomu dubrovačkom govoru, ovisno o tome jesu li prevođeni sa stranih jezika ili su preuzimani iz naših sjevernočakavskih, pa i kajkavskih ili pak južnijih čakavskih predložaka. Zato i predstavljaju neprocjenjiv izvor za istraživanje uključenosti štokavskih dubrovačkih (ćiriličkih) pisaca i supisaca u dominantna književnojezična strujanja hrvatskoga 15. i 16. stoljeća: čakavsko-(kajkavsko)-crkvenoslavenska, čakavska i kajkavska (uz začinjanje tronarječnoga tipa); a pismovno gledano glagoljička i latinička (usp. Malić 1980: 148-150).

\section{JEZIČNO REDIGIRANJE ČAKAVSKOGA TEKSTA U ŠTOKAVSKOME LIBRU OD MNOZIJEH RAZLOGA}

\subsection{Cilj i korpus istraživanja}

Opis jezika Libra od mnozijeh razloga koji je sastavio Milan Rešetar veoma je iscrpan (1933b), što ne znači da ne ostavlja prostora za nova istraživanja. U skladu s temeljnim filološkim preokupacijama vremena u kojemu djelu-

12 Rešetar navodi (1933b: 94): „Od ostalih članaka 5. dijela odvaja se Skazanje od 12 petaka (br. 34) već time što ni u jednome od njih, pa uopće ni u jednome drugom članku Zbornika nema toliko i tako jakih tragova od crkvenoslavenskoga jezika, tako da se u njemu svaki čas nailazi ili na koji oblik ili na koju riječ crkvenoga jezika, n. pr. va edinomu gradu, prienie (raspra), žitie (život), da-se ona dva prita 2, imenemb, sve-vidacb 3, pripriel-me esi, od gorosti (bolesti) 4, u-hramini (u kući), nače-ga pitati 5, svetago i-časnago 15 itd. Već se dakle po tome vidi da je ovo Skazanje drukčije udešeno negoli ostali članci ovoga Zbornikova dijela, jer dok su ovaki elementi, koji nisu dubrovački, u njemu česti i upućuju više na crkveni jezik, u ostalim su člancima rijetki i upućuju više na čakavski govor ili, da bolje rečemo, na glagoljsko-čakavski 'književni' jezik."

13 „Jezične varijacije (dijatopijske, stilističke, dijakronijske) među varijantama jednoga teksta mogu ukazati i na moguće varijacije u negdašnjoj jezičnoj uporabi." (Kapetanović 2012: 22, prema Barbarić 2017: 19) 
je, osnovni je Rešetarov cilj, kako je ranije već navedeno, rekonstrukcija dubrovačkoga govora na kraju 15. i početkom 16. stoljeća (1933b: 116). Da bi stekao taj uvid, služio se samo proznim tekstovima iz Libra s obzirom na to da se jezik poezije u takve svrhe može rabiti tek u ograničenoj mjeri. Budući da jezik pjesama iz Libra Rešetaru dakle nije bio osobito zanimljiv, ovdje usmjeravamo svoju pozornost upravo na taj dio.

Pjesništvo je u Libru od mnozijeh razloga zastupljeno putem šest pjesama: Od smrti čtenje (Nu mislimo, bratjo, što smo) (br. 3), Pjesma o kraljici nebeskoj (br. 8), Istorija od svetoga Đurđa (br. 11), Molim te, Bože moj, kti mi milos dati (br. 23), Probudi se jure, duše (br. 31), Molitva od Gospođe (br. 45), a tomu se možda mogu pribrojiti i pojedini drugi tekstovi s obzirom na poteškoće u razgraničavanju proze i stiha (Žagar i Grmača 2020: 50-53). Dvije se od tih pjesama mogu dovesti u vezu s glagoljičkom Pariškom pjesmaricom iz druge polovice 14 . stoljeća, ${ }^{14}$ no nisu iz nje prepisane, a riječ je o pjesmama Od smrti čtenje (Nu mislimo, bratjo, što smo) i Probudi se jure, duše (Žagar i Grmača 2020: 50). Dolores Grmača slaže se s Rešetarovom pretpostavkom da su u inačicama iz Libra sačuvane starije redakcije obiju pjesama, dok je redakcija sačuvana u inačicama iz Pariške pjesmarice mlađa (Rešetar 1933b: 109-110; Žagar i Grmača 2020: 50). Ista autorica prepoznat će dijelove Pariške pjesmarice i u Istoriji od svetoga Đurđa, što prethodno nije zamijećeno u literaturi (Žagar i Grmača 2020: 52). S obzirom na to da samo za navedene dvije od ukupno šest pjesama raspolažemo mogućnošću usporedbe s drugim poznatim inačicama u hrvatskim pjesmaricama iz prethodnih stoljeća, naš je korpus istraživanja naposljetku načinjen od njihovih inačica iz Pariške pjesmarice i Libra od mnozijeh razloga. ${ }^{15}$

Cilj je ovoga istraživanja utvrditi kategorije u kojima se provodi štokaviziranje u našem korpusu, a potom na temelju usporedbe s kategorijama u kojima je međudijalektna adaptacija zamijećena u dosadašnjoj literaturi o

14 Godine 1905. Josip Vajs objavio je prvu transliteraciju Pariške pjesmarice ćirilicom (1905: 260-275). Godine 1969. Vjekoslav Štefanić objavio je njezinu latiničku transkripciju (1969: 364-373, 377-378, 385-387, 397-399, 421-426). Godine 1972. Dragica Malić objavila je latiničku transliteraciju i transkripciju (1972: 34-67), a novu će latiničku transkripciju objaviti trideset godina kasnije (Malić 2002: 653-671). Posljednje je izdanje Pariške pjesmarice ono koje su ponudili Amir Kapetanović, Dragica Malić i Kristina Štrkalj Despot u latiničkoj transkripciji (2010).

15 U početku je u naše istraživanje trebala biti uključena i pjesma Istorija od svetoga Đurđa, no ta je zamisao kasnije napuštena jer se ne može provesti jednak tip usporedbe kao za odabrane pjesme. 
hrvatskim ranonovovjekovnim tekstovima utvrditi stupanj njihova preklapanja. ${ }^{16} \mathrm{Da}$ se u dvjema pjesmama koje su ovdje odabrane „uklanjaju čakavske markantne značajke teksta (npr. jekavizacija, zamjena $\check{c} a>s ̌ s o, k i>k o j i$, Ljd. m. r. $-i>-u$ )", zamijetio je već Amir Kapetanović (2010: XLIV). Naša je polazna pretpostavka da se čakavsko-štokavska jezična prilagodba provodi $\mathrm{u}$ istim kategorijama u objema pjesmama i da zahvaća ponajprije fonološku razinu. ${ }^{17} \mathrm{Je}$ li to doista tako, provjerit ćemo u nastavku.

\subsection{Prvi primjer: Od smrti čtenje (Nu mislimo, bratjo, što smo)}

Pjesma Od smrti čtenje nalazi se u Libru na listovima 28r-v (Žagar 2020b: 155-156). Osim u toj knjizi nalazimo je dva stoljeća ranije u Pariškoj pjesmarici pod naslovom Nad grobom [pojut] g(lago)l̦će sije, a potom u još tri inačice iz 15. i 16. stoljeća: u Zborniku duhovnoga štiva (bez naslova), Klimantovićevu zborniku I. i Klimantovićevu zborniku II. (u obama zbornicima pod naslovom Šekvencija nad grobom kada telo v grob položet) (Malić 1972: 53-57; Kapetanović, Malić i Štrkalj Despot 2010: 175-190). Već je iz prvoga stiha zamjetna razlika u osnovici na kojoj je utemeljen književni jezik sačuvanih inačica: u četirima je primjerima riječ o čakavskoj (Tu mislimo, bratja, ča smo), ${ }^{18}$ a u jednome primjeru o štokavskoj osnovici (Nu mislimo, bratjo, što smo), koje jasno identificira upitno-odnosna zamjenica. Iako ne smatramo da je štokavska inačica iz Libra nastala izravno na temelju

16 Naravno, bitno je naglasiti da izravan predložak dubrovačkih lekcionara u kojima je zasvjedočena čakavsko-štokavska prilagodba pouzdano znamo, što se ne može reći i za Libro. Stoga valja imati na umu da raščlambom u nastavku ne želimo sugerirati da su čakavski predlošci kojima se služimo prilikom usporedbe bili izravnim predloškom odgovarajućim člancima iz Libra, već ih uzimamo samo kao model. Štoviše, predlošci tekstovima koji dolaze u Libru nisu ni morali biti pisani, već su mogli biti i usmeni. Na to nas je upozorila kolegica Dolores Grmača, na čemu joj ovom prilikom zahvaljujemo.

17 Indikatori štokavskoga obrata daju se međutim pronaći i na drugim jezičnim razinama, čemu može posvjedočiti jedan primjer iz motrene pjesme: Ogńiti hoće naši skuti, / a ostati gńili šćuti. Dragica Malić (2011: 93) naime ističe pjesmaričin leksem šćuti naspram Klimantovićeva Rituala koji bilježi sjevernodalmatinski žńuti te dubrovačkoga Libra s oblikom štuci (potkoljenične kosti; ogniti će . naši . skuti . ostati će . goli . ĉuci), što znači da je u svakom spomeniku uporabljena lokalna, razumljiva riječ istoga ili sličnoga značenja - gole kosti.

18 U jeziku četiriju čakavskih inačica nema bitnijih razlika (Kapetanović, Malić i Štrkalj Despot 2010: 176). U tome je kontekstu zanimljivo izdvojiti uporabu likova ličnih zamjenica u I jd.: tobu, sobu u južnočakavskoj Pariškoj pjesmarici nasuprot tobom, sobom u sjevernočakavskim inačicama, dok bismo očekivali obrnutu situaciju (Kapetanović 2010: XL-XLI). 
čakavske inačice iz Pariške pjesmarice, ta je pjesma odabrana ovdje za prvi primjer u kojemu možemo pratiti štokavsko redigiranje čakavskoga teksta. Obje se inačice donose usporedno u sljedećoj tablici: ${ }^{19}$

\begin{tabular}{l|l}
\hline Pariška pjesmarica, druga polovica 14. st. & Libro od mnozijeh razloga, 1520. \\
\hline $\begin{array}{l}\text { Tu mislimo, bratja, ča smo, } \\
\text { razumijmo zemla da smo! }\end{array}$ & $\begin{array}{l}\text { Nu mislimo, bratjo, što smo, } \\
\text { razumijemo zemḷa da smo! }\end{array}$ \\
\hline $\begin{array}{l}\text { Slast i dika tvoj'ga tila } \\
\text { hoće biti kal i gńila. }\end{array}$ & $\begin{array}{l}\text { Slast i dika tijela našega } \\
\text { skoro bude kao i gńila. }\end{array}$ \\
Tako naše tilo gine, & Kada naše tijelo izgne, \\
tako naša slava mine. & $\underline{\text { tadaj naša slava mine. }}$ \\
\hline Grišnici se teško hine & $\underline{\text { Grješnici se teško hine }}$ \\
to videće, ki zlo čine, & toj videći, tere zlo čine. \\
ko vidiše ńega tilo & Toj vidimo naše tijelo \\
skoro hoće biti gńilo. & skoro hoće biti gńilo, \\
Malo hoće dni isteći, & paki malo dni isteći \\
sami h'ćemo tako leći. & sami ćemo takoj leći. \\
Vijmo skazan pred očima: & $\underline{\text { Viđmo skazan prid očima, }}$ \\
zanosi nas smrtna plina. & zanosi nam smrtna plima. \\
Na nas hoće skoro priti, & Na nas hoće skoro priti, \\
ne more nas to grišiti. & ne može nas toj griješiti. \\
To smrt nosi ostru kosu, & Toj smrt nosi oštru kosu \\
otpasti je s lica nosu. & otpasti je s lica nosu. \\
Ocire se naši zubi, & $\underline{\text { Ocijeriti će se naši zubi, }}$ \\
$\underline{\text { vsi ležemo tamni v grobi. }}$ & $\underline{\text { svi ležimo tamni, grubi. }}$ \\
Ogńiti hote naši skuti, & Ogńiti će naši skuti, \\
a ostati gńili šćuti. & ostati će goli šćuti. \\
Smrt nas, bratja, moćno žańe, & Smrt nas, bratjo, moćno žńe, \\
a mi li zli nišćemańe. & a mi zli i ništamańe. \\
Kada človika semrt postigne, & Kada čovjeka smrt postigne, \\
tada ot ńega vsak pobigne. & tadaj od ńega svak pobjegne. \\
\hline
\end{tabular}

19 Latinička transkripcija pjesme Nad grobom [pojut] glagoluće sije (Tu mislimo, bratja, ča smo) preuzeta je iz izdanja Kapetanović, Malić i Štrkalj Despot 2010: 178-181, gdje je objavljena njezina zadnja transkribirana inačica, no uz nekoliko odstupanja: na mjestu grafema ě pišemo $i$, ne prenosimo oble zagrade, opredjeljujemo se za čitanje gńil- i vazmu nasuprot vzmu. Dragica Malić uvjerljivo je na temelju rime dokazala da u jeziku Pariške pjesmarice valja pretpostaviti ikavski odraz jata, što upućuje na „srednjodalmatinski ikavski izgovor jata” (1972: 100), odnosno na to „da je spomenik iz gotovo posve ikavskog kraja, svakako južnije od Zadra, negdje oko Splita" (1972: 110). Od toga odstupa ekavski odraz jata u prijedlogu pred i prefiksu pre- (Malić 1972: 109-110). Latinička transkripcija pjesme Od smrti čtenje (Nu mislimo, bratjo, što smo) napravljena je pak za potrebe ovoga rada na temelju latiničkoga prijepisa koji je priredio Mateo Žagar (2020b: 155-156). 


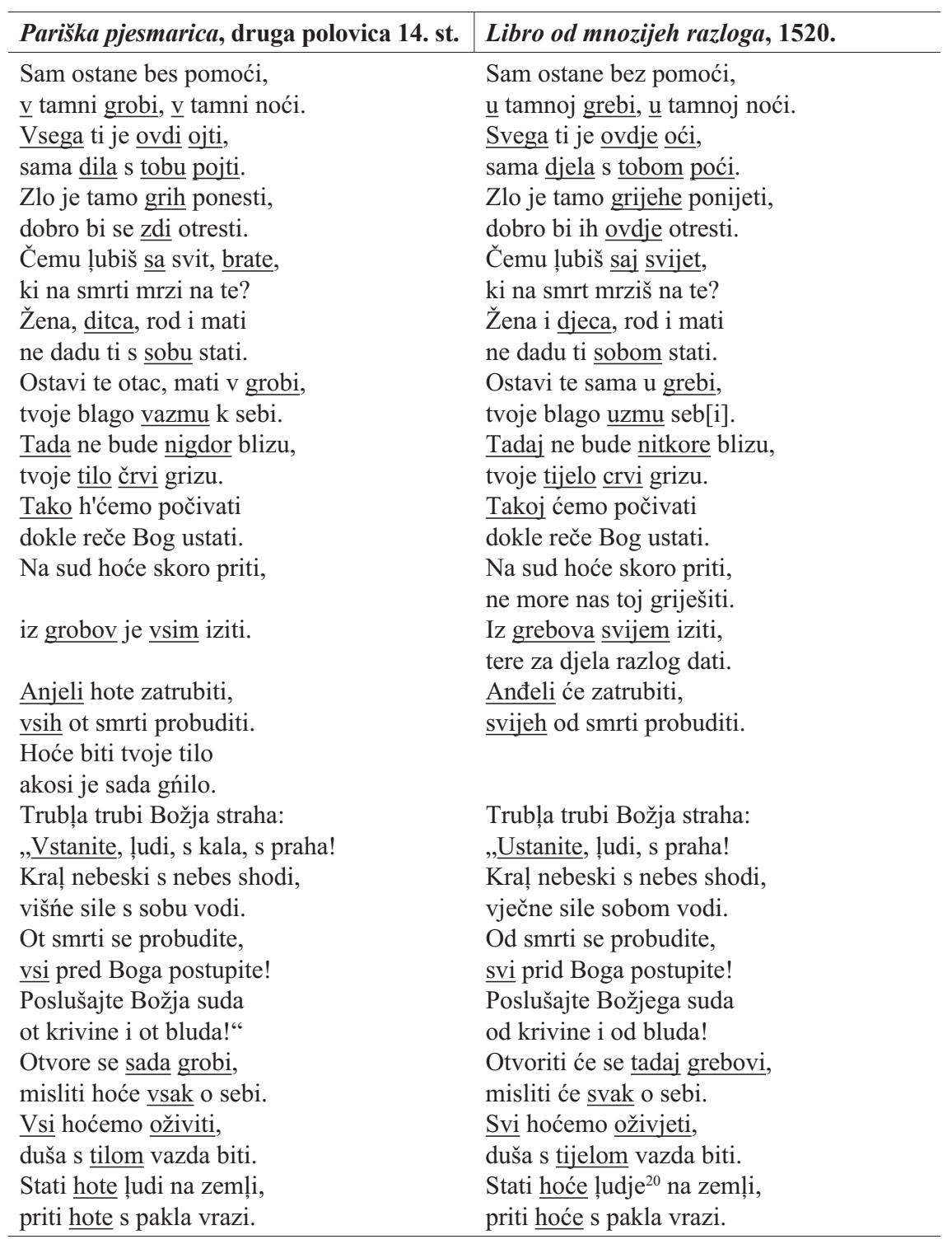

20 Ovakvi bi primjeri možda mogli ukazivati na stariji predložak Libra u odnosu na Parišku pjesmaricu (stari gramatički morfem za $\mathrm{N}$ mn. i-promjene). 


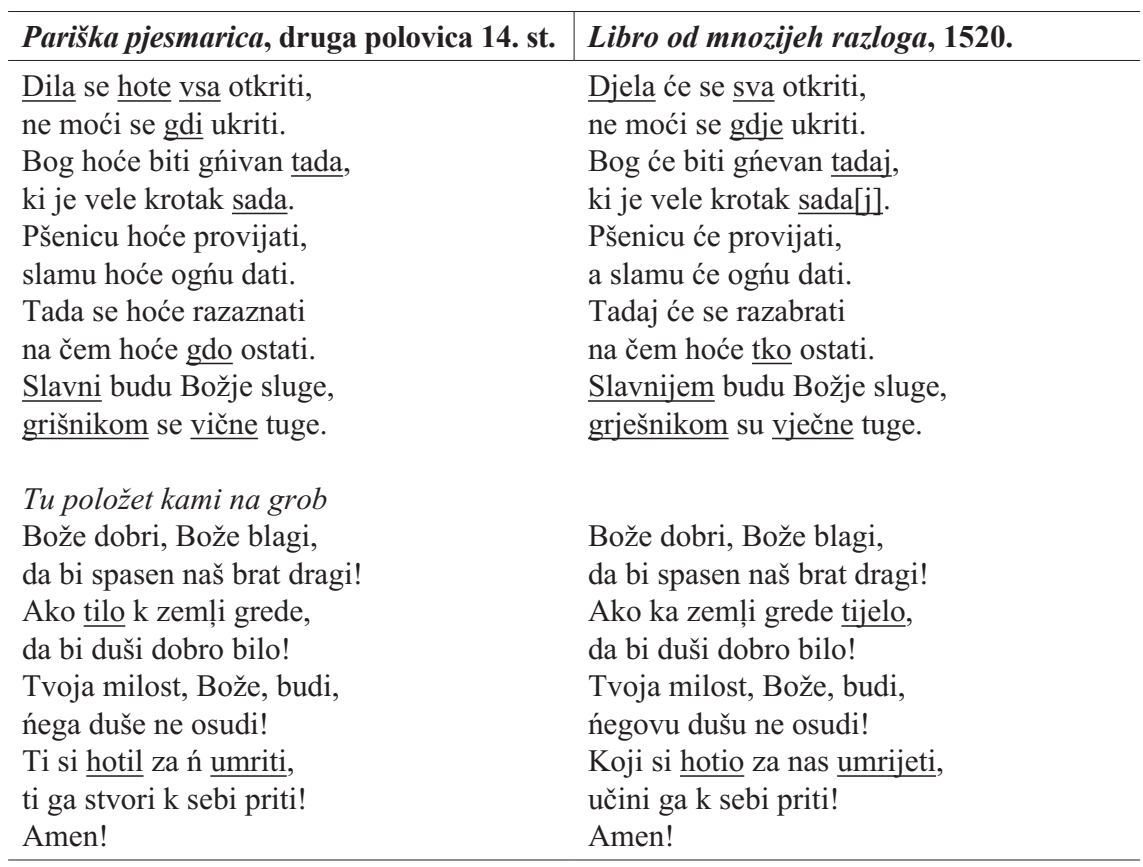

U dosadašnjoj je literaturi već upozoreno na to da je inačica iz Libra poštokavljena i jekavizirana, čime je narušen rimarij pjesme, odnosno ishodišni parno rimovani osmerac (Kapetanović, Malić i Štrkalj Despot 2010: 175-176). U nastavku detaljnije prikazujemo koje su sve kategorije zahvaćene jezičnom prilagodbom, pričem naša pozornost nije usmjerena na sve jezične razlike, nego samo one koje su znakovite u kontekstu hrvatskih čakavsko-štokavskih prijevoda (usp. i Kapetanović, Malić i Štrkalj Despot 2010: 176).

Ikavski refleks jata mijenja se u (i)jekavski u korijenskim, tvorbenim i gramatičkim morfemima: razumijmo $>$ razumijemo, tila $>$ tijela, tilo $>$ tijelo, grišnici > grješnici, grišiti > griješiti, ocire se $>$ ocijeriti će se, človika > čovjeka, pobigne $>$ pobjegne, ovdi $>$ ovdje, dila $>$ djela, grih $>$ grijehe, zdi $>$ ovdje, svit > svijet, ditca > djeca, vsim > svijem, vsih > svijeh, oživiti $>$ oživjeti, tilom > tijelom, gdi $>$ gdje, grišnikom > grješnikom, vične > vječne, umriti $>$ umrijeti. Da se prilikom provođenja te prilagodbe nije uvijek vodilo računa o posljedicama koje će ostaviti na stih, zorno pokazuju sljedeći primjeri: štok. Toj vidimo naše tijelo / skoro hoće biti gńilo. naspram čak. ko vidiše nega tilo / skoro hoće biti gńilo.; štok. Kada čovjeka smrt postigne, / 
tadaj od ńega svak pobjegne. naspram čak. Kada človika semrt postigne, / tada ot ńega vsak pobigne.; štok. Svi hoćemo oživjeti, / duša s tijelom vazda biti. naspram čak. Vsi hoćemo oživiti, / duša s tilom vazda biti.; štok. Koji si hotio za nas umrijeti, učini ga $k$ sebi priti! naspram čak. Ti si hotil za umriti, / ti ga stvori $k$ sebi priti!, u kojim je primjerima jekaviziranjem jata narušena rima. Slično je i u sljedećem primjeru: čak. Ako tilo k zemḷi grede, / da bi duši dobro bilo! naspram štok. Ako ka zeml̦i grede tijelo, / da bi duši dobro bilo! U tome primjeru pravilna rima nije ostvarena ni u čakavskoj ni u štokavskoj inačici: u prvoj bi imenica tilo trebala doći na kraju stiha, dok u drugoj ona i dolazi na pravome mjestu, ali jekaviziranjem je jata izgubljena rima sa sljedećim stihom.

Odraz je jotacije dentala /d/ u čakavskoj inačici /j/, a u štokavskoj /d/: vijmo > viđmo, a tako je prilagođeno $\mathrm{i} / \mathrm{g} / \mathrm{u}$ posuđenicama iz klasičnih jezika: anjeli $>$ anđeli.

Prijedlog i prefiks $v(a)$ mijenja se $u u: v>u$, vazmu $>u z m u$, vstanite $>$ ustanite.

Finalno je slogovno /1/ neizmijenjeno u čakavskoj inačici, dok je u štokavskoj inačici vokalizirano u /o/: $\mathrm{kal}>\mathrm{kao}$, hotil > hotio.

Zamjenice i prilozi dobivaju navezak u štokavskoj inačici: tako: tadaj, to $>$ toj, tako > takoj, tada > tadaj, sa > saj, sada: tadaj.

$\mathrm{U}$ korijenskome morfemu imenice grob provodi se promjena korijenskoga vokala u štokavskoj inačici: grobi > grebi, grobov > grebova, grobi $>$ grebovi.

U infinitivu složenica glagola iti kojima se ispred infinitivnoga nastavka nalazi vokal provedena je metateza i jotacija u štokavskoj inačici: ojti > oći, pojti > poći. Tako nije u primjerima priti, iziti, koji su u objema inačicama zastupljeni u istome liku.

Početna suglasnička skupina $v s$ - u zamjeničkim oblicima čuva se neizmijenjena u čakavskoj inačici, dok se u štokavskoj inačici provodi metateza $s v$-: $v s i>s v i, v s a k>$ svak, vsega $>$ svega, vsim $>$ svijem, vsih $>$ svijeh, vsa $>$ sva.

Početna je suglasnička skupina $\check{c} r$ - neizmijenjena u čakavskoj inačici, dok je u štokavskoj inačici promijenjena u $c r$-: čarvi $>c r v i$.

Početna je suglasnička skupina $c ̌ l$-neizmijenjena u čakavskoj inačici, dok je u štokavskoj /1/ reducirano: človika > čovjeka.

Čakavska upitno-odnosna zamjenica za neživo zamjenjuje se štokavskom: $\check{c} a>\check{s} t o$, a slična je opreka i u primjeru nišće $>n i s ̌ t a$.

Čakavska (i ne samo čakavska) upitno-odnosna zamjenica za živo zamjenjuje se štokavskom: gdo $>$ tko, nigdore $>$ nitkore. 
U instrumentalu jednine ličnih zamjenica rabi se gramatički morfem $/ \mathrm{u} /$ u čakavskoj inačici, a u štokavskoj inačici /om/: tobu > tobom, sobu > sobom.

U množini jednosložne imenice grob osnova se proširuje nerelacijskim morfemom /ov/ u štokavskoj inačici: grobov > grebova, grobi > grebovi.

U genitivu množine imenica muškoga roda rabi se gramatički morfem /ov/ u čakavskoj inačici, a u štokavskoj inačici /a/ (iza nerelacijskoga morfema /ov/, kojim je osnova proširena u svim množinskim padežima): grobov $>$ grebova.

U 3. 1. mn. prezenta glagola htjeti rabi se tipični čakavski oblik hote, dok u štokavskoj inačici dolazi hoće.

\subsection{Drugi primjer: tužba Probudi se jure, duše}

Pjesma Tužba: Probudi se jure, duše nalazi se u Libru na listovima 149r-152r (Žagar 2020b: 407-413). Njezin drugi dio nalazimo dva stoljeća ranije u Pariškoj pjesmarici pod naslovom Poj žel̦no! (Zač mi tužiš, duše) (Ivšić 1932; Malić 1972: 62-67; Kapetanović, Malić i Štrkalj Despot 2010: 227-231). Ne smatrajući ni u ovome slučaju da je čakavska inačica iz Pariške pjesmarice bila izravnim predloškom štokavske inačice iz Libra, ta je pjesma odabrana ovdje za drugi primjer u kojemu možemo pratiti štokavsko redigiranje čakavskoga teksta. Obje se inačice donose usporedno u sljedećoj tablici: ${ }^{21}$

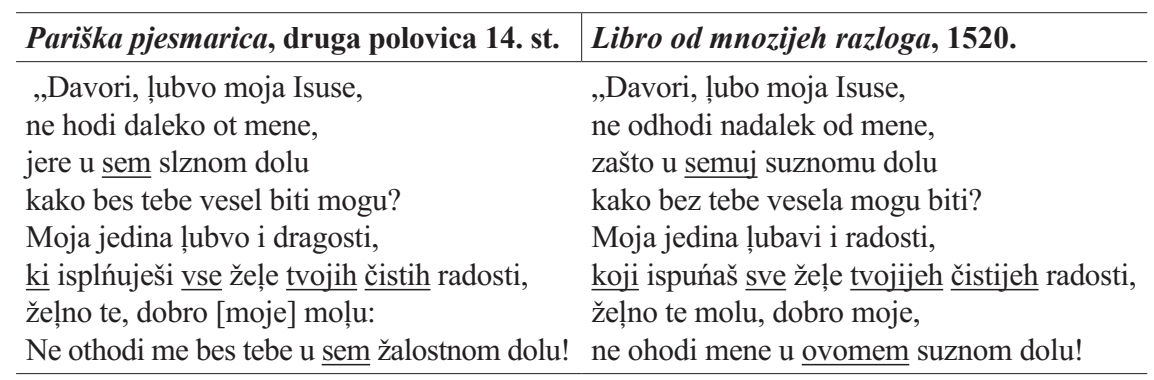

21 Latinička transkripcija obiju inačica preuzeta je iz izdanja Kapetanović, Malić i Štrkalj Despot 2010: 265-269, gdje je objavljena njihova zadnja transkribirana inačica, no odstupamo od nje priklanjajući se bilježenju ikavskoga odraza jata u inačici iz Pariške pjesmarice i zanemarujući oble zagrade. 


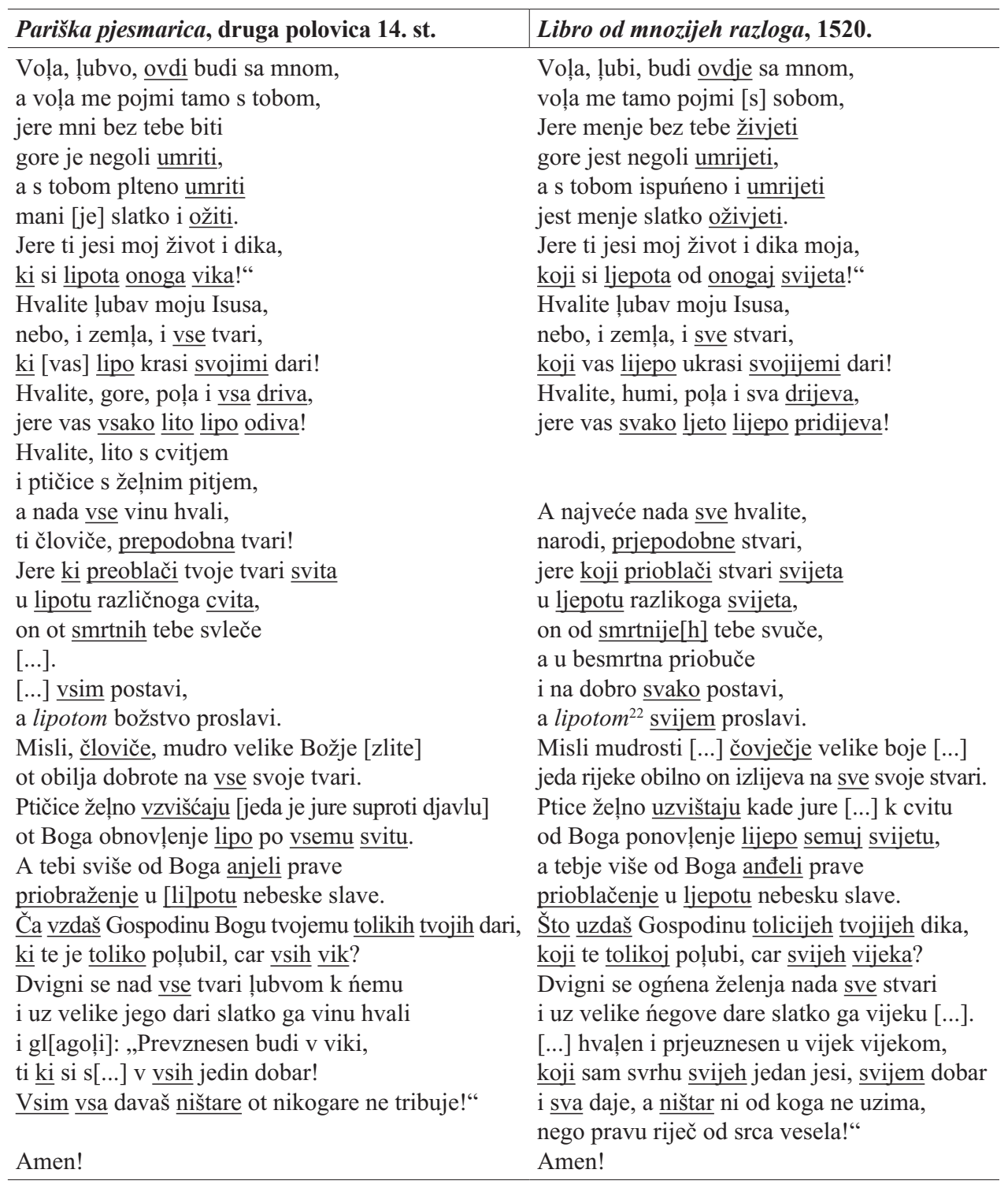

22 Ovdje odstupamo od čitanja ali potom u Kapetanović, Malić i Štrkalj Despot 2010: 268. 
Proces poštokavljenja i jekavizacije pretpostavljenoga čakavskog predloška, već uočen u dosadašnjoj literaturi o toj pjesmi, narušio je i u ovome primjeru ishodišni rimarij pjesme (Kapetanović, Malić i Štrkalj Despot 2010: 227). U nastavku ponovno detaljnije prikazujemo kategorije zahvaćene jezičnom prilagodbom, usmjeravajući pozornost samo na one jezične razlike znakovite u kontekstu hrvatskih čakavsko-štokavskih prijevoda. Dok je u prvoj pjesmi bilo lakše pratiti jezično raslojavanje, druga pjesma nalaže složeniju usporedbu jer u njoj valja računati i s utjecajem hrvatskoga crkvenoslavenskog jezika, a k tomu valja dodati i veći broj razlika među dvjema inačicama uopće.

Ikavski refleks jata mijenja se u (i)jekavski u korijenskim, tvorbenim i gramatičkim morfemima: tvojih $>$ tvojijeh, čistih $>$ čistijeh, ovdi $>$ ovdje, umriti $>$ umrijeti, ožiti $>$ oživjeti, lipota $>$ ljepota, lipo > lijepo, svojimi $>$ svojijemi, driva $>$ drijeva, lito $>$ ljeto, lipo $>$ lijepo, odiva $>$ pridijeva, svita $>$ svijeta, smrtnih $>$ smrtnijeh, lipotu $>$ ljepotu, človiče $>$ čovječje, svitu $>$ svijetu, tolikih $>$ tolicijeh, vsih $>$ svijeh, vik $>$ vijeka, vsim $>$ svijem. Primjeri vzvišćaju $>$ uzvištaju te lipotom iz štokavske inačice pokazuju da jekavizacija nije provedena u apsolutnoj mjeri. Od toga odstupa odraz jata u prefiksu prě-, koji se iz ekavskoga u čakavskoj inačici mijenja u ikavski u štokavskoj inačici (dubrovački ikavizam): preoblači > prioblači, ali ne i u primjerima prepodobna : prjepodobne, prevznesen > prjeuznesen.

Prefiks $v(a)$ mijenja se u $u$ : vzvišćaju > uzvištaju, vzdaš > uzdaš, prevznesen $>$ prjeuznesen.

Odraz je jotacije dentala /d/ u čakavskoj inačici /j/, a u štokavskoj /d/, a tako je prilagođeno $\mathrm{i} / \mathrm{g} / \mathrm{u}$ posuđenicama iz klasičnih jezika: anjeli $>$ anđeli.

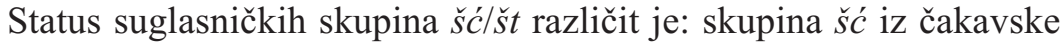
inačice zamijenjena je skupinom št u štokavskoj inačici u primjeru vzvišćaju $>$ uzvištaju.

Zamjenice i prilozi dobivaju navezak u štokavskoj inačici: $s e m$ : semuj, onoga > onogaj, vsem: semuj, toliko > tolikoj, sem : ovomem.

Početna suglasnička skupina $v s$ - čuva se neizmijenjena u čakavskoj inačici, dok je u štokavskoj inačici premetnuta u $s v$-: vse $>$ sve, vsa $>$ sva, vsako $>$ svako, vsih > svijeh, vsim > svijem.

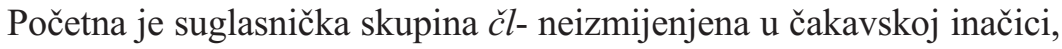
dok je u štokavskoj /1/ reducirano: človiče : čovječje.

Čakavska upitno-odnosna zamjenica za neživo zamjenjuje se štokavskom: $\check{c} a>\check{s}$ to, ali primjer ništar(e) zajednički je objema inačicama. 
U genitivu množine imenica muškoga roda rabi se ništični gramatički morfem u čakavskoj inačici, a u štokavskoj inačici /a/: vik > vijeka.

U čakavskoj inačici rabe se samo kontrahirani oblici upitno-odnosne zamjenice, koji se u štokavskoj inačici zamjenjuju nekontrahiranima: $k i>k o j i$.

\subsection{Komentar}

Naša polazna pretpostavka o tome da se čakavsko-štokavska jezična prilagodba provodi u istim kategorijama u objema pjesmama i da zahvaća ponajprije fonološku razinu samo je djelomično točna, kako su pokazali rezultati poduzetoga istraživanja. Iako su kategorije u kojima se prilagodba provodi više-manje podudarne, zamjetno je da ona ne zahvaća samo fonološku nego i morfološku razinu. Na tim su dvjema razinama potvrđene ove zajedničke promjene: (i)jekaviziranje ikavskoga odraza jata, prilagodba odraza jotacije dentala $/ \mathrm{j} />/ \mathrm{d} /$, prilagodba prijedloga i prefiksa $v(a)>u$, uvođenje naveska u zamjenica i priloga, prilagodba početne suglasničke skupine $v s->s v$-, redukcija /1/ u početnoj suglasničkoj skupini $\check{c} l$-, zamjena upitno-odnosne zamjenice $\check{c} a>$ što, uvođenje morfema /a/ u G mn. imenica muškoga roda. Tomu valja dodati i promjene zasvjedočene u samo jednoj pjesmi, npr. vokaliziranje finalnoga slogovnoga /1/ > /o/ na dočetku riječi, provedba metateze i jotacije u infinitivu složenica glagola iti, prilagodba suglasničkih skupina $\check{s} \check{c}>\check{s} t$, prilagodba početne suglasničke skupine $\check{c} r->c r$ - Kako su pokazali navedeni primjeri, prilagodba nije provedena u apsolutnoj mjeri, odnosno ne zahvaća beziznimno sve primjere u kojima postoje uvjeti za njezinu provedbu. Unatoč tomu možemo ustvrditi da nam navedene kategorije ukazuju na to koje su jezične razlike među čakavštinom i štokavštinom bile smatrane najuočljivijim obilježjima tih dvaju sustava, odnosno koje je bilo nužno prilagoditi drugoj (književno)jezičnoj zajednici.

\section{JEZIČNO REDIGIRANJE ČAKAVSKOGA TEKSTA U ŠTOKAVSKOJ I KAJKAVSKOJ SREDINI U 16. ST.}

Libro od mnozijeh razloga nije jedini primjer jezičnoga redigiranja izvorno čakavskoga teksta u štokavskoj sredini u dubrovačkoj ćiriličkoj pismenosti 16. stoljeća. U studiji o jeziku Libra Rešetar ustvrđuje da je takva prilagodba zamjetna i u dvama dubrovačkim ćiriličkim lekcionarima 16. stoljeća: 
Dubrovačkome dominikanskom lekcionaru i Lajpciškome lekcionaru, čiji je predložak bio Bernardinov lekcionar, ${ }^{23}$ a gdje su ,čakavsko-dalmatinske osobine, prilično konzekventno, zamijenjene štokavsko-dubrovačkim.” (Rešetar 1933b: 118) Štoviše, Rešetar uočava da su slova koja je pisao pisar A iz Libra i slova iz Dubrovačkoga dominikanskog lekcionara jednaka, što bi značilo da ih je pisao isti pisar, samo bi taj lekcionar po njegovu mišljenju nastao ili u isto vrijeme ili ranije (Rešetar 1933b: 119-120). ${ }^{24}$

Povezanost dubrovačkih šesnaestostoljetnih ćiriličkih lekcionara s Bernardinovim lekcionarom uočena je još krajem 19. stoljeća. Usporedivši biblijsku lekciju Iv 5,1 iz Bernardinova lekcionara s odgovarajućom lekcijom u Lajpciškome lekcionaru iz treće četvrtine 16. stoljeća, August Leskien zaključuje da je riječ o različito obojenu jeziku (anders gefärbtem Dialekt), dok je tekst identičan (Leskien 1881: 204-206). Sličan zaključak o razlici među tim dvama lekcionarima donosi i Tomislav Maretić priređujući kritičko izdanje Bernardinova lekcionara: „samo su gdjekoji oblici i glasovi iz čakavskoga govora okrenuti na dubrovački." (Maretić 1885: XVII)

U suvremenoj hrvatskoj filologiji predložen je novi termin za takvo „okretanje na dubrovački govor” o kojemu pišu Maretić i Rešetar. Govoreći o nastajanju i jezičnome oblikovanju hrvatskih lekcionara, posebno onih nastalih u 16. stoljeću, Vuk-Tadija Barbarić uvodi termine vertikalno i horizontalno prevođenje - izvorno uvedene u teoriju književnoga prevođenja od Gianfranca Folene - gdje se prevođenje s čakavskoga na štokavski može smatrati tipom horizontalnoga prevođenja, dok bi prevođenje s crkvenoslavenskoga na ta dva jezična sustava bilo primjerom vertikalnoga prevođenja (Barbarić 2017: 144, 149). Prema Foleni, a što prihvaća Barbarić, tri su temeljna kriterija za određivanje tipa prevođenja: prestiž, struktura i kulturna bliskost (Barbarić 2017: 149).

Za vertikalno prevođenje vrijedi da:

1. ishodišni jezik ima veći prestiž u odnosu na ciljni jezik

2. ishodišni jezik postaje uzor/model (čak i kalup) za ciljni jezik

3. ishodišni jezici, kojih su primjeri latinski, grčki i arapski, pripadaju udaljenim kulturama te su strukturno različiti.

23 Predloškom je Dubrovačkom dominikanskom lekcionaru bilo prvo izdanje Bernardinova lekcionara (1495), a Lajpciškom lekcionaru drugo izdanje Bernardinova lekcionara, tzv. Zborovčićev lekcionar (1543) (Rešetar 1933a; Barbarić 2011: 22-24; Barbarić 2012; Barbarić 2017: 106-107; Kapetanović 2014).

24 I na drugome mjestu: ,isti čovjek što je pisao glavni dio Zbornika pisao je i glavni prepis Lekcionara." (Rešetar 1933b: X) 
Za horizontalno prevođenje vrijedi da:

1. ishodišni i ciljni jezik imaju približno jednak prestiž

2. ishodišni jezici, kojih su primjeri romanski i germanski jezici, međusobno su kulturno bliski (tj. među njima postoji »forte affinità culturale«) i slične su strukture. (Barbarić 2017: 145)

Zahvaljujući takvim povijesnosociolingvističkim uvidima možemo zaključiti da se međudijalektna adaptacija zasvjedočena $u$ hrvatskim šesnaestostoljetnim tekstovima ima dakle smatrati horizontalnim prevođenjem u užem smislu. Da taj proces u hrvatskome ranonovovjekovlju nije bio ograničen funkcionalnim registrom, dokazuje činjenica da ga nalazimo i u paraliturgijskome (lekcionari) i u neliturgijskome (Libro od mnozijeh razloga) korpusu. Dodajmo tomu da su mahom zastupljeni čakavsko-štokavski prijevodi, ali nalazimo i čakavsko-kajkavske, kako ćemo pokazati u nastavku. Nakon što smo utvrdili razine horizontalnoga prevođenja u jeziku pjesništva Libra od mnozijeh razloga, preostaje nam sada ih sagledati u kontekstu hrvatskih međudijalektnih adaptacija 16. stoljeća.

Čakavsko-štokavsko prevođenje možemo ilustrirati pomoću inačica biblijske lekcije Iv 5,1 iz Bernardinova i Lajpciškoga lekcionara na temelju kojih je Leskien uočio bliskost tih dvaju lekcionara:

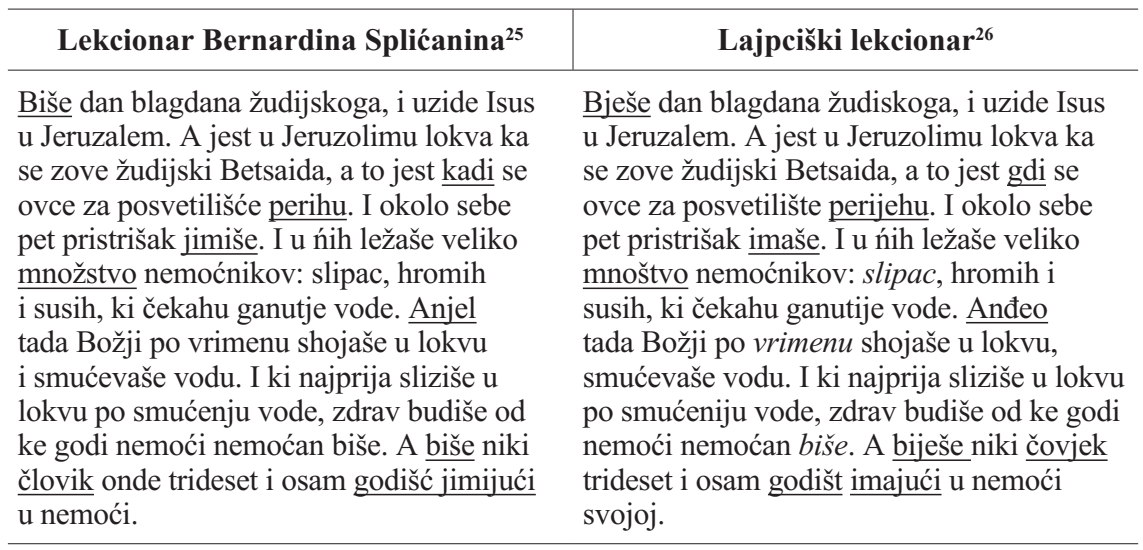

\footnotetext{
${ }^{25}$ Ova se inačica donosi prema izdanju Barbarić i Štrkalj Despot 2020: 40-41.

${ }^{26}$ Ova se inačica transkribira prema izdanju Leskien 1881: 205-206.
} 


\begin{tabular}{|c|c|}
\hline Lekcionar Bernardina Splićanina ${ }^{25}$ & Lajpciški lekcionar ${ }^{26}$ \\
\hline 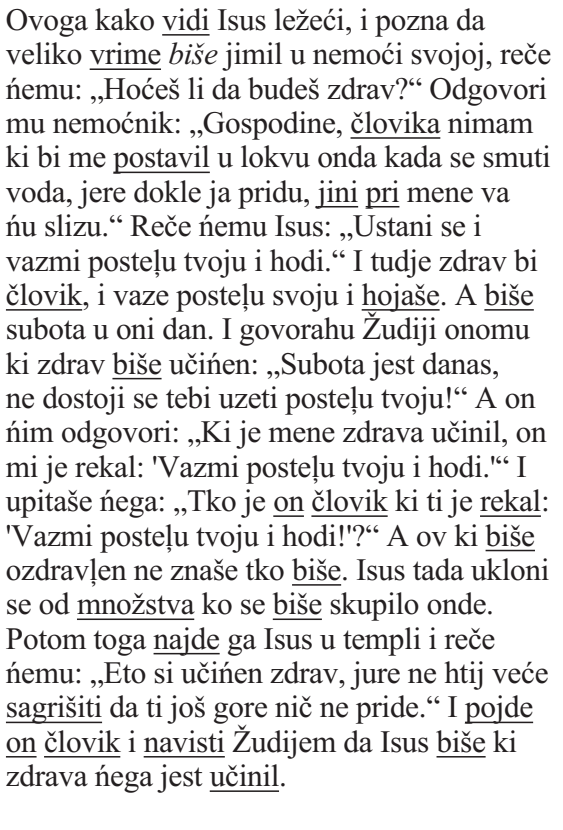 & $\begin{array}{l}\text { Ovoga kako vidje Isus ležeći, i pozna da } \\
\text { veliko vrijeme biše gnjil u nemoći svojoj, } \\
\text { reče ńemu: Hoćeš li da budeš zdrav? } \\
\text { Odgovori mu nemoćnik: Gospodine, } \\
\text { čovjeka ne imam ki bi me postavio u } \\
\text { lokvu onda kada se smuti voda, jere dokle } \\
\text { ja pridu, ini prije mene u ńu slizu. Reče } \\
\text { nemu Isus: Ustani se i vazmi postel̦u tvoju i } \\
\text { hodi. I tudje zdrav bi čovjek, i vaze postel̦u } \\
\text { svoju i hođaše. A bješe subota u oni dan. } \\
\text { I govorahu Žudiji onomu ki zdrav bješe } \\
\text { učińen: Subota jest danas, ne dostoji se tebi } \\
\text { uzeti postel̦u tvoju! A on ńim odgovori: } \\
\text { Ki je mene zdrava učinio, on mi je rekao: } \\
\text { Vazmi postelu tvoju i hodi. I upitaše } \\
\text { ńega: Tko je oni čovjek ki ti je rekao: } \\
\text { Vazmi postelu tvoju i hodi!? A ov ki bješe } \\
\text { ozdravlen ne znaše tkǒ bješe. Isus tada } \\
\text { ukloni se od mnoštva ko se bješe skupilo } \\
\text { onde. Potom toga nađe ga Isus u templi i } \\
\text { reče ńemu: Eto si učińen zdrav, jure ne htij } \\
\text { veće sagriješiti da ti još gore nije ne pride. I } \\
\text { pođe oni čovjek i navijesti Žudijem da Isus } \\
\text { bješe ki zdrava ńega jest učinio. }\end{array}$ \\
\hline
\end{tabular}

Usporedba dviju inačica predočenih u tablici otkriva da je čakavski predložak štokaviziran u prvome redu na fonološkoj razini: (i)jekaviziranjem ikavskoga odraza jata, prilagodbom odraza jotacije dentala /j/ / / d/, a slično i u primjeru anjel $>$ anđeo, zatim vokaliziranjem finalnoga slogovnoga $/ 1 />/ 0 /$ na dočetku riječi, uklanjanjem protetskoga $/ \mathrm{j} /$, provedbom metateze i jotacije u prezentu složenica glagola iti te prilagodbom suglasničkih skupina $\breve{s} c$ > $s ̌ t$. Da to redigiranje nije bilo apsolutno sustavno, pokazuje nam primjerice izostanak očekivanoga (i)jekaviziranja jata u riječima slipac, vrimenu ili biše (u desnome stupcu tablice označeni kurzivom).

Vrlo je zanimljivo zapažanje Milana Rešetara o sustavnosti provedbe jezičnoga redigiranja čakavskoga izvornika u štokavskoj sredini na primjeru Bernardinova, odnosno Lajpciškoga lekcionara. Rešetar primjećuje da jezičnim redigiranjem nisu zahvaćene sve kategorije u kojima su se ta dva

\footnotetext{
${ }^{27}$ Leskien pogrešno navodi da u Lajpciškome lekcionaru na ovome mjestu piše kto; u izvorniku zapravo stoji tko. Na to nas je upozorio kolega Vuk-Tadija Barbarić, na čemu mu zahvaljujemo.
} 
jezična sustava razlikovala, nego „samo ono što im je najviše smetalo a nisu zamjenjivali baš sve čega u njihovu govoru nije bilo". (Rešetar 1933a: 31) Na temelju pogrešaka prepisivača može se pretpostaviti i da pojedine čakavske riječi nisu razumjeli, zbog čega štokavska adaptacija čakavskoga predloška nije uvijek podjednako uspjela. ${ }^{28}$ Vuk-Tadija Barbarić navodi nekoliko takvih primjera: npr. pogrešno razumijevanje /k/ umjesto /ć/ u infinitivima brići $>$ briki 'svetkovati' i oblići $>$ obliki 'obući', priloga listo $>$ isto 'istom' te automatizmom provedenu izmjenu /j/ $>/ \mathrm{d} /$ u primjeru tolikoje $>$ itolikođe unatoč tomu što se ne radi o jotaciji dentala (Barbarić 2011: 17-19; Barbarić 2014: 5-6; Barbarić 2017: 108). Tomu možemo dodati i zanimljiv Rešetarov primjer iz Libra od mnozijeh razloga: jedini primjer u kojemu je zadržano neizmijenjeno finalno slogovno /1/ jest riječ prijal, koju je, drži Rešetar, „dubrovački redaktor slijepo prepisao ne razumjevši toga oblika” s obzirom na to da se $\mathrm{u}$ tome zborniku rabi isključivo infinitiv primiti, a ne i prijati (1933b: 181).

Čakavsko-kajkavsko prevođenje slabije je pak poznato. Na jedan je takav primjer nedavno pozornost filološke javnosti skrenula Ivana Eterović (2021), prikazujući razine na kojima se horizontalno prevođenje provodi u Postili Antuna Vramca, otisnutoj u Varaždinu 1586. godine. Usporedivši pojedine isječke iz toga djela s Bernardinovim lekcionarom i biblijskim prijevodima hrvatskih protestanata, autorica zaključuje da je osnovna, iako ne i jedina, razina prilagodbe - fonološka. ${ }^{29}$ Među zamijećenim redaktorskim izmjenama možemo izdvojiti sljedeće: prilagođava se odraz poluglasa /a/ > /e/, odraz stražnjega nazala /u/ > /o/ i odraz samoglasnoga /1/ > /o/, ikavski odraz jata mijenja se u ekavski, uvode se protetski suglasnici $/ \mathrm{v} / \mathrm{i} / \mathrm{j} /$ te

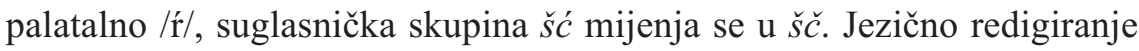
čakavskoga predloška u kajkavskoj sredini nije provedeno posve sustavno, što taj proces čini podudarnim s čakavsko-štokavskom prilagodbom i u jeziku pjesama Libra od mnozijeh razloga i u dubrovačkim lekcionarima.

28 Već je Rešetar istaknuo da se malo pažnje posvećivalo tom tipu čakavsko-štokavskih odnosa, zbog čega je nastojao sastaviti rječnik onih čakavskih riječi koje su štokavski prepisivači smatrali neobičnima (Rešetar 1933a: 87; prema Barbarić 2017: 98-99).

29 Usporedbe radi zanimljivo je ovdje skrenuti pozornost na to da je i u redakcijama i recenzijama staroslavenskoga jezika temeljna preobrazba bila fonološke naravi, čega su bili svjesni čak i devetnaestostoljetni obnovitelji hrvatskoga crkvenoslavenskog jezika, ističući kako su glasovne preinake bile na prvoj liniji adaptacije, uz povremenu uporabu novijih riječi (tako su pisali D. A. Parčić 1882. u svojoj raspravi Za obstanak glagoljice te I. Radetić u udžbeniku Predavanja o knjigi staroslovenskoj 1896, usp. Blažević Krezić 2021: 262). 


\section{ZAKLJUČAK}

Zbornik pretežno nabožnoga sadržaja Libro od mnozijeh razloga izvrstan je primjer na kojemu se može pokazati smjena znanstvene paradigme u hrvatskoj filologiji. Dok je iscrpna studija Milana Rešetara, objavljena prije gotovo stotinu godina, jednim od hrvatskih devetnaestostoljetnih filoloških vrhunaca, suvremeni pogled na njegov jezik, kako je pokazano u ovome radu na primjeru dviju pjesama iz toga zbornika, oslanjajući se čvrsto na dosege prethodnikā, ukazuje na nove plodne smjerove budućih istraživanja. Umjesto rekonstrukcije objektivnih jezičnih razlika između čakavštine i štokavštine u 16. stoljeću u naš je fokus ovdje bilo postavljeno utvrđivanje njihova subjektivna doživljaja u svijesti onodobnih govornika (dubrovačke) štokavštine - drugim riječima, njihova percepcija. Podudarnost kategorija zahvaćenih štokaviziranjem ne samo u odabranim dvjema pjesmama iz Libra od mnozijeh razloga nego i u lekcionarskome korpusu, a nemojmo zaboraviti ni primjer horizontalnoga prevođenja u kajkavskoj sredini - mahom na fonološkoj razini, ali i na drugima - prokazuje nam čakavsko-štokavske razlike koje je štokavska sredina mogla smatrati glavnima/tipičnima za drugi sustav, a koje je zbog toga u njoj trebalo izmijeniti, čime nam posredno pomaže i u boljem razumijevanju odnosa među hrvatskim narječjima i dijalektima u ranome novovjekovlju.

\section{LITERATURA}

Barbarić, Vuk-Tadija. 2011. Lajpciški lekcionar i njegovi »predlošci«. Rasprave Instituta za hrvatski jezik i jezikoslovlje, XXXVII, 1, 1-28.

Barbarić, Vuk-Tadija. 2012. Nove spoznaje o Lajpciškom lekcionaru. Rasprave Instituta za hrvatski jezik i jezikoslovlje, XXXVIII, 1, 1-18.

Barbarić, Vuk-Tadija. 2014. Prema analizi prepisivačkih pogrešaka u dubrovačkim ćiriličkim prijepisima Bernardinova lekcionara. Filologija, 63, 1-15.

Barbarić, Vuk-Tadija. 2017. Nastajanje i jezično oblikovanje hrvatskih lekcionara. Zagreb: Institut za hrvatski jezik i jezikoslovlje.

Barbarić, Vuk-Tadija; Štrkalj Despot, Kristina [prir. i ur.]. 2020. Bernardinov lekcionar 1495. Zagreb: Institut za hrvatski jezik i jezikoslovlje.

Blažević Krezić, Vera. 2021. Popularnim slogom o knjigi staroslovenskoj ili Skica za portret ćirilometodijanca Ivana Radetića. Od Pavlimira do riči šokačke. Zbornik Ljiljane Kolenić [ur. Silvija Ćurak i Vera Blažević Krezićc. Osijek: Filozofski fakultet Sveučilišta J. J. Strossmayera u Osijeku. 239-278. 
Damjanović, Stjepan. 1984. Tragom jezika hrvatskih glagoljaša. Zagreb: Hrvatsko filološko društvo.

Damjanović, Stjepan. 2014. Novi filološki prinosi. Zagreb: Matica hrvatska.

Damjanović, Stjepan. 2012. Slovo iskona. Staroslavenska / starohrvatska čitanka. Zagreb: Matica hrvatska.

Damjanović, Stjepan. 2016. Izvori i rukavci hrvatske glagoljičke baštine. Zagreb: Hrvatska sveučilišna naklada.

Eterović, Ivana. 2021. Mjesto Postile Antuna Vramca među hrvatskim horizontalnim prijevodima 16. stoljeća. Zbornik Diane Stolac [ur. Borana Morić Mohorovičić i Anastazija Vlastelić]. Filozofski fakultet Sveučilišta u Rijeci. U tisku.

Franičević, Marin. 1964. Književne interpretacije. Zagreb: Naprijed.

Hercigonja, Eduard. 2006. Tropismena i trojezična kultura hrvatskoga srednjovjekovlja. Zagreb: Matica hrvatska.

Ivšić, Stjepan. 1932. Jedna hrvatska glagolska pjesma iz 14. vijeka u Libru od mnozijeh razloga. Građa za povijest književnosti hrvatske, 11, 1-10.

Jagić, Vatroslav. 1868. Prilozi k historiji književnosti naroda hrvatskoga i srbskoga. Zagreb.

Kapetanović, Amir. 2010. Najstarije hrvatsko pjesništvo. U: Kapetanović, Amir; Malić, Dragica; Štrkalj Despot, Kristina [prir.]. 2010. Hrvatsko srednjovjekovno pjesništvo: pjesme, plačevi i prikazanja na starohrvatskom jeziku. Zagreb: Institut za hrvatski jezik i jezikoslovlje. XV-LIX.

Kapetanović, Amir. 2011. Čakavski hrvatski književni jezik. Povijest hrvatskoga jezika. 2. knjiga: 16. stoljeće [gl. ur. Ante Bičanić]. Zagreb: Croatica. 77-123.

Kapetanović, Amir. 2012. Varijantni srednjovjekovni tekstovi i njihova leksikografska obrada. Filologija, 59, 15-24.

Kapetanović, Amir. 2014. Jezična uporaba u ćiriličnom Dubrovačkom dominikanskom lekcionaru. Filologija, 62, 61-68.

Kapetanović, Amir; Malić, Dragica; Štrkalj Despot, Kristina [prir.]. 2010. Hrvatsko srednjovjekovno pjesništvo: pjesme, plačevi i prikazanja na starohrvatskom jeziku. Zagreb: Institut za hrvatski jezik i jezikoslovlje.

Leskien, August. 1881. Das dalmatinisch-serbische cyrillische Missale romanum der Leipziger Stadtbibliothek. Berichte über die Verhandlungen der königlich sächsischen Gesellschaft der Wissenschaften zu Leipzig. Philologisch-historische Classe 33. 199- 250 .

Lisac, Josip. 2009. Hrvatska narječja u srednjem vijeku. Povijest hrvatskoga jezika 1: Srednji vijek [gl. ur. Ante Bičanić]. Zagreb: Croatica. 261-281.

Lisac, Josip. 2011. Hrvatska narječja. Povijest hrvatskoga jezika 2: 16. stoljeće [gl. ur. Ante Bičanić]. Zagreb: Croatica. 51-75.

Lovrić Jović, Ivana. 2014. O starome dubrovačkom govoru. Zagreb: Institut za hrvatski jezik i jezikoslovlje. 
Lukežić, Iva. 2012. Zajednička povijest hrvatskih narječja 1. Fonologija. Zagreb, Rijeka, Čavle: Hrvatska sveučilišna naklada, Filozofski fakultet u Rijeci, Katedra Čakavskoga sabora Grobnišćine.

Lukić, Milica. 2009. Vojislav P. Nikčević kao istraživač ćirilometodske problematike (Nacrt). Lingua Montenegrina: časopis za jezikoslovna, književna i kulturna pitanja, 3, 19-31.

Lukić, Milica. 2011. Strossmayerov projekt obnove ćirilometodske baštine. Anali Zavoda za znanstveni i umjetnički rad u Osijeku, 27, 67-96.

Malić, Dragica. 1972. Jezik najstarije hrvatske pjesmarice. Zagreb: Hrvatsko filološko društvo.

Malić, Dragica. 1980. Pravci razvoja hrvatskoga književnog jezika do ilirskog razdoblja: pokušaj sinteze. Rasprave: časopis Instituta za hrvatski jezik i jezikoslovlje, 6-7, 1, 141-162.

Malić, Dragica. 1993. Konsonantizam Žića svetih otaca. Rasprave: časopis Instituta za hrvatski jezik i jezikoslovlje, 19, 1, 179-212.

Malić, Dragica. 2002. Na izvorima hrvatskoga jezika. Zagreb: Matica hrvatska.

Malić, Dragica. 2011. Odjeci najstarije hrvatske pjesmarice u Marulićevim stihovima. Colloquia Maruliana, 20, 20, 75-102.

Malić, Dragica. 2014. Suodnos tiskanoga Ciriličkoga dubrovačkog molitvenika i rukopisnoga latiničkoga Drugoga vatikanskog. Filologija, 62, 139-160.

Maretić, Tomislav. 1885. Lekcionarij Bernardina Spljećanina po prvom izdanju od god. 1495. Zagreb: JAZU.

https://ia800704.us.archive.org/8/items/djelajugoslaven00umjegoog/djelajugoslaven00 umjegoog.pdf (pristupljeno 13. svibnja 2021.).

Mihaljević, Milan. 2009. Hrvatski crkvenoslavenski jezik. Povijest hrvatskoga jezika. 1. knjiga: Srednji vijek [gl. ur. Ante Bičanić]. Zagreb: Croatica. 283-349.

Nazor, Anica. 2014. Hrvatski ćirilički molitvenik iz 1512. godine. Filologija, 62, 17-31.

Paskojević, Kristijan. 2018. Razvojni procesi diplomatičke ćiriličke minuskule u dokumentima srednjovjekovne dubrovačke kancelarije. Doktorski rad. Zagreb: Filozofski fakultet Sveučilišta u Zagrebu.

Raukar, Tomislav. 1973. O problemu bosančice u našoj historiografiji. Radovi Muzeja grada Zenice, III, 103-144.

Rešetar, Milan. 1926. Libro od mnozijeh razloga. Dubrovački ćirilski zbornik od g. 1520. Srijemski Karlovci: Srpska kraljevska akademija.

Rešetar, Milan. 1933a. Bernardinov lekcionar i njegovi dubrovački prepisi. Beograd: Srpska kraljevska akademija.

Rešetar, Milan. 1933b. Dubrovački zbornik od god. 1520. Beograd: Srpska kraljevska akademija.

Štefanić, Vjekoslav. 1938. Jakov Ledesma i njegov „Nauk karstianski“ (1583.). Vrela i prinosi. Zbornik za povijest isusovačkoga reda u hrvatskim krajevima. Posebno izdanje br. 2. Zagreb: Filozofsko-teološki institut Družbe Isusove, Hrvatski povijesni institut u Beču. 
Štefanić, Vjekoslav i sur. [prir.]. 1969. Hrvatska književnost srednjega vijeka. Zagreb: Zora - Matica hrvatska.

Vajs, Josip. 1905. Starohrvatske duhovne pjesme. Starine, 31, 258-275.

Vončina, Josip. 1987. Uloga Hanibala Lucića u formiranju jezika hrvatskoga renesansnog pjesništva. Dani Hvarskoga kazališta, 13, 1, 137-143.

Vugrinec, Jasminka. 2010. Legenda o dvanaest petaka iz Tkonskog zbornika. Čakavska rič, XXXVIII, 1-2, 227-272.

Vulić, Sanja. 2011. Štokavski hrvatski književni jezik. Povijest hrvatskoga jezika 2: 16. stoljeće [gl. ur. Ante Bičanić]. Zagreb: Croatica. 125-187.

Vulić, Sanja. 2016. Jezična previranja u dubrovačkoj renesansnoj književnosti. Colloquia Maruliana, 25, 229-255.

Zaradija Kiš, Antonija; Šimić, Marinka. 2020. Cvijet kreposti ili o naravi ljudskoj kroz narav životinjsku, studija - transliteracija - faksimil. Zagreb: Hrvatska sveučilišna naklada, Institut za etnologiju i folkloristiku, Staroslavenski institut.

Zelić Bućan, Benedikta. 2000. Bosančica ili hrvatska ćirilica u srednjoj Dalmaciji. Split: Državni arhiv.

Žagar, Mateo i Kristijan Paskojević. 2014. Ćiriličke isprave dubrovačke kancelarije 15. stoljeća između minuskule i kurziva. Filologija, 62, 221-247.

Žagar, Mateo. 2008. Grafetičke posebnosti tekstova istočne grane hrvatskoga glagoljaštva. Slovo, 56-57, 695-708.

Žagar, Mateo. 2009. Hrvatska pisma u srednjem vijeku. Povijest hrvatskoga jezika - 1 . knjiga: Srednji vijek [gl. ur. Ante Bičanić]. Zagreb: Croatica. 107-219.

Žagar, Mateo. 2014. Bosančica Divkovićevih izdanja između ustava, minuskule i brzopisa. Zbornik radova sa znanstvenog skupa Matija Divković i kultura pisane riječi [ur. Marko Karamatić]. Sarajevo: Franjevačka teologija Sarajevo, Kulturno-povijesni institut Bosne Srebrene. 147-172.

Žagar, Mateo. 2016. Uvodna riječ. U: Žagar, Mateo; Ferenčak, Ivan [prir.]. 2016. Ofičje Blažene Djeve Marije i Petnaest molitava Svete Bridžide. Venecija 1512. (latinički prijepis ćiriličkog izvornika). Zagreb: Hrvatska sveučilišna naklada. 5-49.

Žagar, Mateo. 2020a. Lejla NAKAŠ, Paratekstualnost u bosanskoj srednjovjekovnoj književnosti, Forum Bosnae 83-84/18, Međunarodni Forum Bosna, Sarajevo 2019., 120 str. Slovo, 70, 314-319.

Žagar, Mateo [prir.]. 2020b. Libro od mnozijeh razloga 1520. Latinički prijepis s komentarima. Zagreb: Matica hrvatska.

Žagar, Mateo; Grmača, Dolores. 2020. Libro od mnozijeh razloga u hrvatskoj filologiji. U: Žagar, Mateo [prir.]. 2020. Libro od mnozijeh razloga 1520. Latinički prijepis s komentarima. Zagreb: Matica hrvatska. 9-97.

Žagar, Mateo. 2021. Dubrovačka ćirilička baština - kontinuitet i kontekst, neobjavljeni članak. 


\section{SUMMARY}

\section{A LOOK AT THE POETIC LANGUAGE OF LIBRO OD MNOZIJEH RAZLOGA IN THE CONTEXT OF 16тн CENTURY CROATIAN INTER-DIALECTAL ADAPTATIONS}

In the Croatian Cyrillic corpus, texts from Dubrovnik hold an important place. The Cyrillic manuscript tradition was maintained in Dubrovnik for centuries, encompassing texts in various registers, and it was especially rich in the $16^{\text {th }}$ century. One of the largest texts of Dubrovnik's $16^{\text {th }}$-century Cyrillic corpus is Libro od mnozijeh razloga, a 1520 miscellany of mostly religious content. Milan Rešetar published Libro in its entirety almost 100 years ago, claiming that its chapters had been written under the influence of various source texts adapted to the dialect of Dubrovnik: Glagolitic texts in the vernacular, Cyrillic texts in Old Church Slavonic, Italian texts, and he even found Kajkavian elements. Such an adaptation is not an exclusive feature of Libro od mnozijeh razloga; namely, inter-dialectal adaptation has already been confirmed in other Croatian $16^{\text {th }}$-century texts. In this paper, we show the levels of Chakavian-Shtokavian adaptation in Libro on the example of two of his poems, which are then compared to other examples of Chakavian-Shtokavian and Chakavian-Kajkavian adaptations from the $16^{\text {th }}$ century. The aim is to contribute to a better understanding of the relation among Croatian dialects in the early modern period.

Keywords: Croatian language, $16^{\text {th }}$ century, Cyrillic script, Dubrovnik, Libro od mnozijeh razloga, inter-dialectal adaptation, horizontal translation

Rad je otvorenog pristupa i može se distribuirati sukladno s međunarodnom javnom licencom CC BY-NC-ND 4.0 HR.

This paper is open access and may be further distributed in accordance with the provisions of the CC BY-NC-ND 4.0 HR. 